\section{Linkage Relationships of Isozymes and Morphological Traits in Interspecific Chestnut Crosses}

\author{
H. Huang ${ }^{1}$, F. Dane ${ }^{2}$, and J.D. Norton \\ Department of Horticulture, Auburn University, Auburn, AL 36849 \\ D.B. Weaver \\ Department of Agronomy and Soils, Auburn University, Auburn, AL 36849 \\ F.V. Hebard \\ Wagner Research Farm, The American Chestnut Foundation, Meadowview, \\ VA 24361
}

Additional index words. Castanea dentata, American chestnut, Castanea mollissima,

Chinese chestnut

Abstract. Linkage relationships among eight isozyme genes (Acp-3, Est-1, Est-5, Prx-1, $\operatorname{Pr} x$-2, Prx-3, Me, and $A d h)$ and two morphological markers (Inh and $T w h$ ) were investigated in one $F_{2}$ and two $B C_{1}$ families of interspecific crosses between the American chestnut (Castanea dentata Borkh.) and the Chinese chestnut ( $C$. mollissima Blume). Inh was consistently linked with $\operatorname{Pr} x-1$ and $E$ st-5 in all families. In addition, four other gene pairs, Acp-3-Inh, Acp-3-Prx-1, Me-Inh, and Twh-Inh, were linked in one of the three families investigated. The two isozyme genes and two morphological marker genes were tentatively integrated into one linkage group with the gene order Twh-Inh-Prx-1-Est-5.

The American chestnut breeding program of the American Chestnut Foundation is attempting to transfer the blight resistance of the Chinese chestnut into the American chestnut tree through successive cycles of backcrosses (Burnham, 1988). Time is of the utmost importance in a backcross breeding program since each backcross generation usually requires 5 to 8 years. The number of backcrosses required depends largely on the recovery rate of the traits of the recurrent parent, which depends on the selection efficiency of the traits and the effect of linkage (Fehr, 1978). Markers have been used extensively to improve the selection efficiency in backcross generations (Tanksley and Rick, 1980). Gene linkage studies in chestnut species have been limited due to their long juvenile period and the difficulties in making controlled crosses Hebard (1994) took the first step toward linkage analysis through the genetic analysis of six morphological markers in hybrids between American and Chinese chestnut. The application of isozyme techniques has increased the

Received for publication 23 Oct. 1995. Accepted for publication 12 Mar. 1996. Journal no 11-944742 of the Alabama Agricultural Experiment Station. This research was partially supported by the American Chestnut Foundation. The cost of publishing this paper was defrayed in part by the payment of page charges. Under postal regulations, this paper therefore must be hereby marked advertisement solely to indicate this fact.

${ }^{1}$ Current address: Wuhan Institute of Botany, Academia Sinica, Wuchung Moshan, P.R. China.

${ }^{2}$ To whom reprint requests should be addressed. number of genetic markers in chestnut species (Huang et al., 1994a, 1994b). As part of our continuous effort to establish a linkage map of chestnut species, linkage relationships of eight isozymes and two morphological markers were investigated.

\section{Materials and Methods}

One $\mathrm{F}_{2}$ and two backcross families were supplied by the Wagner Research Farm of the American Chestnut Foundation. The $\mathrm{F}_{2}$ family was developed from controlled crosses becrosses of Chinese and American chestnut. tween two $\mathrm{F}_{1}$ sib trees (R4T52 $\mathrm{x}$ R4T31) derived from the 'Mahogany' Chinese $x$ 'Roxbury' American cross. The $\mathrm{BC}_{1}-\mathrm{AN}$ family was derived from crosses between (American $\mathrm{X}$ 'Nanking') $\mathrm{F}_{1}$ and American trees, the $\mathrm{BC}_{1}$-AR family from (American $\times \mathrm{R} 4 \mathrm{~T} 31$ ) $-\mathrm{F}_{1}$ and American trees. Population sizes of the $\mathrm{F}_{2}$, $\mathrm{BC}_{1}-\mathrm{AN}$, and $\mathrm{BC}_{1}-\mathrm{AR}$ families were 63,50 , and 27 , respectively.

Isozyme assays were conducted on dormant winter buds as described for acid phosphatase, esterase, peroxidase, malic enzyme, and alcohol dehydrogenase (Huang et al., 1994a). The two morphological markers Inh, interveinal hair, and $T w h$, twig hair density, were examined on a single-plant basis at the Wagner Research Farm. Inh is controlled by one dominant gene, while $T w h$ is controlled by two incompletely dominant genes (Hebard, 1994). All loci (Acp-3, Est-1, Est-5, Prx-1, $\operatorname{Prx}-2, \operatorname{Pr} x-3, M e, A d h$, Inh, and Twh) segregated as single-locus Mendelian genes $(P>$ 0.05 ) with the exception of Inh in one family $\left(\mathrm{BC}_{1}-\mathrm{AN}\right)$, where a significant departure from normal segregation $(P=0.01)$ was detected.

Nonrandom joint segregations among all pairwise (45) combinations of loci were analyzed by contingency $\chi^{2}$ analysis to detect linkage relationships. Recombination values between the loci and their standard errors were calculated based on maximum likelihood algorithms (Allard, 1956; Mather, 1951). The computations were facilitated with LINKAGE1 version 3.50 (Suiter et al., 1983) using a significance threshold of 0.05 . In cases where more than one segregation family was available, the combined recombination values were estimated according to the weighted methods suggested by Kramer and Burnham (1947). Before pooling the segregation data, $\chi^{2}$ tests of heterogeneity were conducted to confirm the homogeneity of the crosses at all loci of concern in this study. Where appropriate, gene order was deduced using combined recombination values directly.

Table 1. Linkage relationships among isozyme Prx-1, Est-5, and morphological marker Inh in interspecific

\begin{tabular}{|c|c|c|c|c|c|c|c|c|}
\hline \multirow{2}{*}{$\begin{array}{l}\text { Locus pair } \\
1-2\end{array}$} & \multirow[b]{2}{*}{ Family } & \multirow{2}{*}{$\begin{array}{c}\text { Genotype } \\
\text { locus-2 }\end{array}$} & \multicolumn{3}{|c|}{ Genotype locus-1 } & \multirow[b]{2}{*}{$\chi^{2}$} & \multirow[b]{2}{*}{$P$} & \multirow{2}{*}{$\begin{array}{c}\text { Recombination } \\
\text { value }(\%)\end{array}$} \\
\hline & & & aa & $a b$ & $\mathrm{bb}$ & & & \\
\hline \multirow[t]{6}{*}{ Prx-1-Inh } & $\mathrm{F}_{2}$ & A- & 18 & 30 & 5 & & & \\
\hline & & aа & 1 & 3 & 6 & 15.1 & 0.001 & $19.8 \pm 5.5$ \\
\hline & $\mathrm{BC}_{1}-\mathrm{AR}$ & $\mathrm{Aa}$ & 4 & 10 & --- & & & \\
\hline & & aа & 10 & 3 & --- & 6.3 & 0.012 & $25.9 \pm 8.4$ \\
\hline & $\mathrm{BC}_{1}-\mathrm{AN}$ & $\mathrm{Aa}$ & 10 & 24 & --- & & & \\
\hline & & aa & 12 & 4 & --- & 9.2 & 0.003 & $28.0 \pm 6.4$ \\
\hline Combined estimate & & & & & & & & $23.9 \pm 3.7$ \\
\hline \multirow[t]{4}{*}{ Est-5-Inh } & $\mathrm{F}_{2}$ & A- & 12 & 25 & 16 & & & \\
\hline & & aa & 1 & 9 & 0 & 6.5 & 0.038 & $43.3 \pm 7.6$ \\
\hline & $\mathrm{BC}_{1}-\mathrm{AN}$ & Aa & 12 & 22 & --- & & & \\
\hline & & aa & 11 & 5 & --- & 4.9 & 0.027 & $34.0 \pm 6.7$ \\
\hline Combined estimate & & & & & & & & $38.0 \pm 5.0$ \\
\hline \multirow[t]{7}{*}{ Prx-1-Est-5 } & $\mathrm{F}_{2}$ & aa & 4 & 5 & 10 & & & \\
\hline & & $a b$ & 7 & 20 & 6 & & & \\
\hline & & $\mathrm{bb}$ & 2 & 9 & 0 & 13.6 & 0.009 & $34.8 \pm 5.6$ \\
\hline & $\mathrm{BC}_{1}-\mathrm{AR}$ & aа & 2 & 12 & --- & & & \\
\hline & & $a b$ & 8 & 5 & --- & 6.5 & 0.011 & $25.9 \pm 8.4$ \\
\hline & $\mathrm{BC}_{1}-\mathrm{AN}$ & aа & 17 & 5 & --- & & & \\
\hline & & $a b$ & 6 & 22 & --- & 15.5 & 0.000 & $22.0 \pm 5.9$ \\
\hline Combined estimate & & & & & & & & $26.1 \pm 3.6$ \\
\hline
\end{tabular}




\section{Results and Discussion}

Significant departures from independent assortment between two-locus combinations of Inh, Prx-1, and Est-5 were detected consistently in all families (with the exception of Est$5-$ Inh in $\mathrm{BC}_{1}-\mathrm{AR}$ ) by contingency $\chi^{2}$ analysis (Table 1). This result indicated linkage of Inh to Prx-1, and Inh to Est-5. Prx-1 also was linked to $E s t-5$ with a recombination value of $26.1 \% \pm 3.6 \%$. Therefore, we can conclude that the gene order is Inh-Prx-1-Est-5 (Fig. $1)$. The inability to detect linkage between Est5 and $I n h$ in one $\mathrm{BC}_{1}$ family $\left(\chi^{2}=0.15\right)$ could be a consequence of loose linkage of the genes $(38.1 \% \pm 5.0 \%)$ and relative small sample size.

Nonrandom joint segregation was detected once for four additional gene pairs in the various families. In the $\mathrm{BC}_{1}-\mathrm{AN}$ family, Inh was linked with $M e$ and $\operatorname{Prx}-1$ with similar recombination values, $28.0 \% \pm 6.4 \%$. Since linkage was not detected between $M e$ and Prx-1, Inh could be located between $M e$ and $\operatorname{Pr} x-1$. The recombination value detected between $I n h$ and $T w h$ in the $\mathrm{BC}_{1}$-AN family was $18.7 \pm 10.0$, similar to that reported by Hebard (1994). In the $\mathrm{F}_{2}$ family, linkage was detected between Acp-3, Inh, and Prx-1, suggesting the gene order Acp-3-Inh-Prx-1. However, the respective recombination values of $A c p-3$ $\operatorname{Inh}(43.8 \pm 7.6)$ and Acp-3-Prx-1 (43.8 \pm 6.2) overlapped greatly so that further crosses and tests are needed to clarify the relationship among these three genes. Several genes, Est-1, $\operatorname{Pr} x-2, \operatorname{Pr} x$-3, and $A d h$, assorted independently from each other and the above-mentioned linkage group.

The inability to detect linkage consistently in all families is probably the result of sampling errors because of the relatively loose linkage ( $>28 \%$ ) between the genes and use of several recurrent parent trees in the backcrosses. A distinct advantage for genetic mapping in perennial species is the accumulability of the genotype arrays for each progeny. A comprehensive linkage map in chestnut would be very useful and should facilitate the selection and recovery of timber-type American chestnut with blight resistance in the chestnut breeding program.

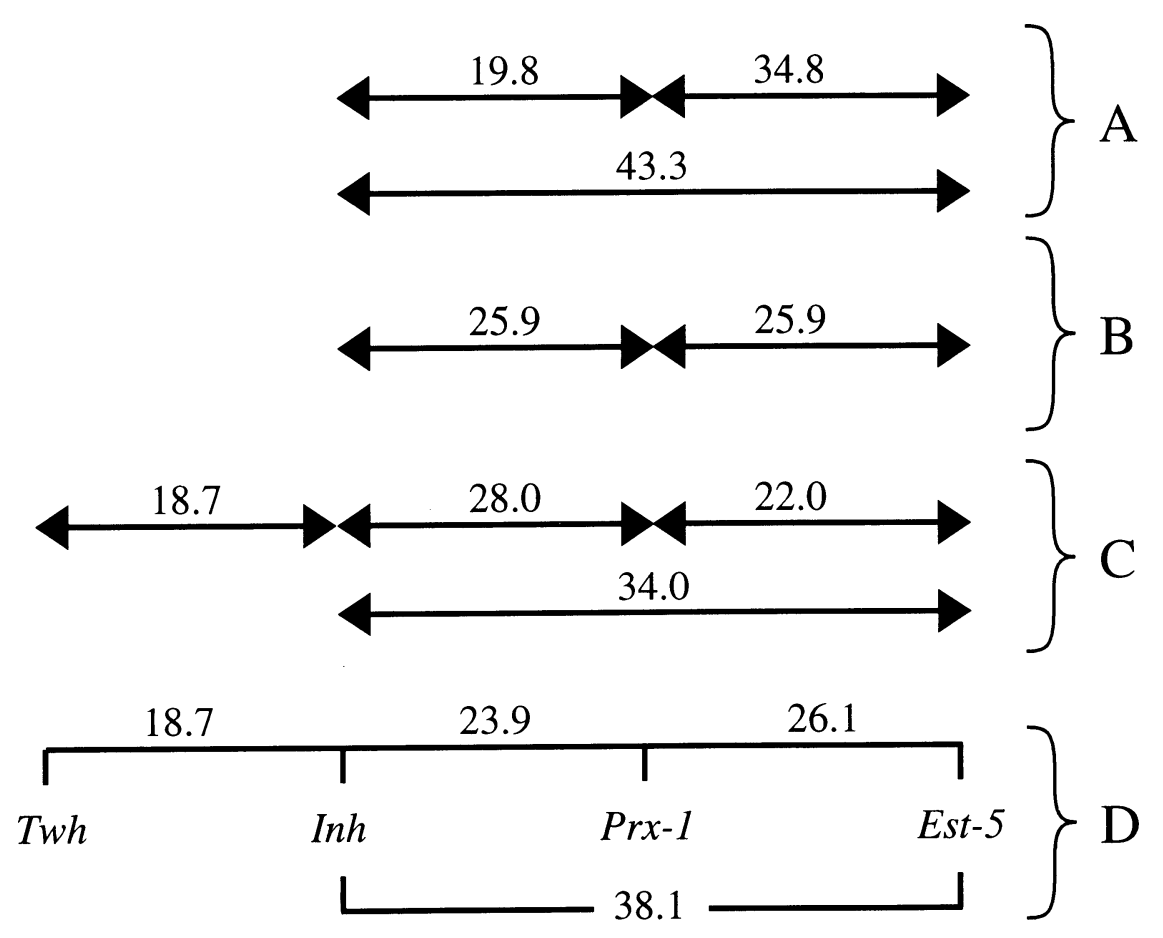

Fig. 1. Tentative linkage map of chestnut between isozyme and morphological loci based on data from (A) $\mathrm{F}_{2}$ between trees R4T52 $\times$ R4T31, (B) backcross between (American $\left.\times \mathrm{R} 4 \mathrm{~T} 31\right)-\mathrm{F}_{1}$ and American trees $\left(\mathrm{BC}_{1}-\mathrm{AR}\right),(\mathbf{C})$ backcross between (American $\mathrm{x}$ 'Nanking')- $\mathrm{F}_{1}$ and American trees $\left(\mathrm{BC}_{1}-\mathrm{AN}\right)$. (D) Combined linkage map with map distances in centimorgan.

\section{Literature Cited}

Allard, R.W. 1956. Formulas and tables to facilitate the calculation of recombination values in heredity. Hilgardia 24:235-278.

Burnham, C.R. 1988. The restoration of the American chestnut. Amer. Scientist 76:478-487.

Fehr, W.R. 1978. Principles of cultivar development. McGraw-Hill, New York.

Hebard, F.V. 1994. Inheritance of juvenile leaf and stem morphological traits in crosses of Chinese and American chestnut. J. Hered. 85:440-446.

Huang, H., F. Dane, and J.D. Norton. 1994a. Genetic analysis of 11 polymorphic isozyme loci in chestnut species and characterization of chestnut cultivars by multi-locus allozyme genotypes. J. Amer. Soc. Hort. Sci. 119:840-849.
Huang, H., F. Dane, and J.D. Norton. 1994b. Allozyme diversity in Chinese, Sequine and American chestnut (Castanea spp). Theor. Appl. Genet. 88:981-985.

Kramer, H.H. and C.R. Burnham. 1947. Methods of combining linkage intensity values from backcross, $\mathrm{F}_{2}$ and $\mathrm{F}_{3}$ genetic data. Genetics 32:379390.

Mather, K. 1951. The measurement of linkage in heredity. Wiley, New York.

Suiter, K.A., J.F. Wendel, and J.S. Case. 1983. LINKAGE-1: A PASCAL computer program for the detection and analysis of genetic linkage. J. Hered. 74:203-204.

Tanksley, S.D. and C.M. Rick. 1980. Isozyme gene linkage map of the tomato: Applications in genetics and breeding. Theor. Appl. Genet. 57:161-170 